\title{
Chapter 13 \\ Potential Explanations for Why People Are Missed in the U.S. Census
}

\begin{abstract}
Knowing the characteristic of people most likely to be missed in the Census is not the same as knowing why they are missed. In this Chapter information is provided on several of the leading ideas about why people are missed in the Census along with data related to many of the ideas. The topic is first approached from broad theoretical perspective then more detailed reasons are examined. The chapter draws heavily on the literature in survey research methodology.
\end{abstract}

\subsection{Introduction}

Most of this book has focused on the characteristics of people and groups that have high census net undercount and omissions rates. But knowing the characteristics of people who are missed is different from knowing why they are missed. This Chapter explores several possible reasons why people are missed in the U.S. Census and examines statistical data related to many of the ideas. Some of the ideas examined here reflect broad factors (like the characteristics of households and living arrangements) and some reflect narrow factors (like the imputation algorithm used by the Census Bureau).

It is widely believed that there is no single reason why people are missed in the Census. With respect to differential undercounts of racial and ethnic groups, de la Puente (1993, p. 2) captured the dominant perspective more than 20 years ago,

Empirically and in the aggregate, there is no single reason why a disproportionate number of ethnic and racial minorities were not counted by the 1990 census. Rather, there are a constellation of factors that interact and contribute to the differential undercount.

The quote above focuses on undercounts by race and ethnicity, but the lack of a single predominant reason for people being missed in the Census goes beyond race and ethnic groups. With respect to the high net undercount of young children, the Census Bureau Task Force on the Undercount of Young Children (U.S. Census Bureau 2014) concluded, "The task force is convinced that there is no single cause for this undercount". 
Despite several reports that address the issue of why people are missed and/or barriers to enumeration in the Census (U.S. Census Bureau 1992; de la Puente 1993; Martin and de la Puente 1993; Simpson and Middleton 1997; Schwede and Terry 2013; West and Fein 1990) there is no consensus framework for examining this issue. Because the Decennial Census is a large and complex operation, there is widespread belief that people are missed in the Census for many different reasons, and researchers approach census omissions from many different disciplines and perspectives, it is not surprising that there is no consensus on the best framework to use for understanding this problem.

\subsection{What Is an Omission?}

Determining what is an omissions in the Census is not as easy as it may seem. For example, in the 2010 Census there were 6 million whole person imputations (U.S. Census Bureau 2012a, Table 6). People are imputed into the Census count if they don't self-respond and there is good evidence they exist (for example, a housing unit that looks occupied), but the Census enumerator can never find anyone at home. If a person does not respond to the Census but data are imputed to represent them in the census count is that an omission?

Also, some households and persons are included in the Census by proxy respondents. If a Census enumerator is unable to contact residents of a household after several attempts, the enumerator may seek data on the household from someone like a neighbor or a landlord. These are referred to as proxy respondents. Should people included in the census count by proxy respondents be called omissions?

It is also important to make a distinction between people who are totally missed in the Census and those who are included but misclassified. For example, if a Black person is included in the Census, but has their race coded as White (perhaps because that characteristic was imputed) that would not impact overall omissions, but it would impact the omissions for Blacks and Whites.

\subsection{Broad Ideas About Why People Are Missed in the Census}

Many of the ideas or theories about why people are missed in the Census are linked to broader questions of non-responsiveness in surveys (National Research Council 2013; Groves and Couper 1998). Several leading theories for understanding omissions in surveys and censuses from a theoretical perspective, including social capital theory, leverage-saliency theory, social exchange theory, are discussed in a report by the National Research Council (National Research Council 2013, pp. 33-36). 
Table 13.1 Why barriers leads to being missed in the census

\begin{tabular}{l|l}
\hline Barrier & How barriers leads to being missed in the census \\
\hline Complex households & $\begin{array}{l}\text { In complex households, more people are likely to be unrelated to the } \\
\text { householder. Respondents are often uncertain whether to include } \\
\text { someone who is not directly related to the householder. In addition } \\
\text { respondents may be confused about concepts such as household and } \\
\text { family and staying temporarily versus living at the census address }\end{array}$ \\
\hline Irregular housing units & $\begin{array}{l}\text { Irregular housing units may not get on the Master Address File and } \\
\text { therefore not receive a Census questionnaire }\end{array}$ \\
\hline Lack or cooperation/trust & $\begin{array}{l}\text { People who don't want to cooperate with the Census Bureau, } \\
\text { because they don't trust the Census Bureau to treat their data } \\
\text { confidentially or for other reasons, are less like to respond to the } \\
\text { Census }\end{array}$ \\
\hline Communication/language & $\begin{array}{l}\text { Respondent who are not comfortable in English may be more } \\
\text { reticent to respond to the Census. For some people, dealing with a } \\
\text { language other than the one they are comfortable with, is just one } \\
\text { more hurdle to participating in the Census }\end{array}$ \\
\hline Renters & $\begin{array}{l}\text { In general renters have less attachment to their community than } \\
\text { home-owners and therefore may be less likely to engage in this civic } \\
\text { activity so they are less likely to respond to the Census. Renters are } \\
\text { also more mobile }\end{array}$ \\
\hline style/non-tradition & $\begin{array}{l}\text { People with lower socio-economic characteristics like poverty, } \\
\text { anemployment and lower levels of education, are pressed by issues } \\
\text { other than the Census. They are less likely to see the salience of } \\
\text { returning a census questionnaire. Some may not even receive a } \\
\text { questionnaire (related to other barriers) }\end{array}$ \\
\hline Residential mobility & $\begin{array}{l}\text { People who are highly mobile around Census day may be moving } \\
\text { between housing units and not receive a census questionnaire. } \\
\text { Renters are also less committed to their community and may not see } \\
\text { the salience or the benefits or returning a census questionnaire }\end{array}$ \\
\hline $\begin{array}{l}\text { These housing units are less likely to be on the Master Address File } \\
\text { and therefore may not receive a Census questionnaire }\end{array}$ \\
\hline Somic status
\end{tabular}

Note This table draws heavily from Appendix 1, in Robinson et al. (2007)

A report by Robinson et al. (2007) lists several barriers to census enumeration and in Appendix 1 of the report they explain how each barrier is tied to the likelihood of being missed in the Census. Table 13.1 lists the barriers offered by Robinson et al. (2007) and a short explanation of how each barrier could results in someone not be counted in the Census.

Other researchers have provided similar ideas about why people are missed in the Census (West and Fein 1990; de la Punte 1993; Schwede et al. 2015). 


\subsection{People Missed in the Census Due to Failure of Steps in the Data Collection Process}

Another approach to understanding why people are missed in the Census is offered by researchers who examine the steps in the data collection process and try to understand which step failed and why (Beimer et al. 1991). Many researchers start by decomposing Census coverage along the lines of Olson (2009) who posits that any omissions in the Census-taking process must come from a failure of one of three steps below;

- Failure to enumerate housing unit,

- Failure to get a complete and accurate roster of household members,

- Failure to get information for a person on the roster.

To reconfigure these three reasons for omissions, the first means the household did not get enumerated, and the second and third, means the household was enumerated, but not everyone in the household who should have been included, was included in the Census count.

\subsection{Missing Households}

Table 13.2 shows 4.2 million housing units were missed in the 2010 Census. Of the 4.2 million housing units missed, 2.2 million were occupied. This estimate is based on comparing the housing units found in the Post-Enumeration Survey to those found in the Census (U.S. Census Bureau 2012a). It is easy to understand why someone living in an overlooked housing unit might be missed in the Census. It is unlikely that the omitted housing units received a census questionnaire and therefore it is unlikely that occupants of those housing units were included in the 2010 Census.

The number of persons in the missed households is not directly available from the Census Bureau, but if the 2.2 million occupied households that were missed had the average number of persons per household in the 2010 Census (2.58) (U.S. Census

Table 13.2 Housing units omitted in the 2010 census

\begin{tabular}{l|l|l|l}
\hline & $\begin{array}{l}\text { Census count of housing } \\
\text { units (in millions }\end{array}$ & $\begin{array}{l}\text { Number omitted (in } \\
\text { millions) }\end{array}$ & Percent omitted \\
\hline U.S. total & 131.7 & 4.2 & 3.2 \\
\hline Occupied & 116.7 & 2.2 & 1.9 \\
\hline Owner-occupied & 76.0 & 1.2 & 1.6 \\
\hline Renter-occupied & 40.7 & 1.0 & 2.5 \\
\hline Vacant & 15.0 & 2.0 & 13.2 \\
\hline
\end{tabular}

Source U.S. Census Bureau (2012a), Table 3 
Bureau 2018a) the missed households would account for 5.7 million missed persons out of a total of almost 16 million omissions in the 2010 Census (U.S. Census Bureau 2012b, Table 2). Missed housing units appears to be a big reason for the high number of omissions in the 2010 Census.

There are several reasons why housing units may be missed in the Census. In some cases, homeowners turn a basement or a garage into a separate housing unit so what appears to be a single-family residence is a multi-unit structure and the new housing units are easy to miss. Mahler (1993) indicates landlords sometime create illegal units in multi-unit structures and they are reluctant to reveal the existence of these units.

In many rural areas housing units may be far off the road and hidden from view and so they are not included in the Master Address File. For example, de la Puente (1993, p. 15) states,

In rural areas, unlike in urban areas, unmarked and/or hidden roads and mismatches between mail delivery address of housing units and the actual physical location of the housing unit are conditions associated with the omissions of housing units from the Census.

Also, in both urban and rural settings Census Bureau canvassers must determine if a housing unit is inhabitable. If a building is deemed uninhabitable it will not receive a Census questionnaire. Making a judgment about the inhabitability of a structure is difficult, despite guidance provided by the Census Bureau; but just as important, some structures that are deemed uninhabitable may actually have people living there. Kissam (2017) and Fein (1989) provide detailed descriptions of some of the many ways housing units are likely to be missed in the Census.

\subsection{People Omitted on Census Questionnaires that Are Returned}

In addition to people who are not counted because their whole household was missed, some people may be missed because they were left off Census questionnaires. People may be omitted because they are left off a questionnaire that was mailed back, missed by an enumerator during the Non-Response Followup operation or possibly missed in another way such as an incorrect proxy response, a data processing error, or incorrect imputation.

Most omissions can be classified as the result of either confusion or concealment. Confusion can lead to a missed person if the respondent is confused about whether a given person should be thought of as part of the household or family and included in the census questionnaire. Confusion can also lead to a person being missed if the respondent is unsure if a certain type of person (like a young child or noncitizen) is supposed to be included in the Census.

Other people may be left off Census questionnaires because the respondent wants to conceal a person or whole household from the authorities. There are many reasons 
why a person might be concealed. For example, some people fear the federal government and they see the Census Bureau as just another federal government agency. Growing fear of the federal government in many communities is likely to be a big factor in the 2020 Census.

\subsection{People Omitted in the Census Because of Confusion}

The "usual place of residence" is a key concept used by the Census, but Martin $(1999,2007)$ argues that concept is not always clear to respondents and attachment to a single household may not apply to some people. Martin talks about the concept of "residential ambiguity" which reflects uncertainty about whether an individual belongs to a housing unit or household. Moreover, most of the rules respondents usually use to determine who they think lives in their household (economic contributions, doing household chores, receiving mail at the address) are not the rules used in the Census, so respondents may be confused about the concepts of families and households used in the Census. According to West and Robinson (1999, p. 10),

The Census rules of residence instruct that the person in whose name the house or apartment is owned, being bought or rented be listed as person 1 on the form. The respondent is then asked to identify members of the household in relation to person 1 . This often contradicts the respondent's notion of family or household.

It is easy to understand how someone who is only marginally attached to a housing unit may be missed in the Census. Whoever is filling out the Census questionnaire for a household may think the marginally attached person does not really live in the housing unit, so they are not entered on the Census roster. It is also feasible that the person filling out the census questionnaire may think someone who does not live at a housing unit continuously, for example, children in joint custody or someone who travels on business regularly, is being counted elsewhere. In reporting on confusion on the part of respondents in the 2010 Census, Schwede and Terry (2013, p. 89) concluded, "Additionally, the situation of mobility of people cycling between housing units and trying to determine from time spent in each where they should be counted was a reason for inconsistencies".

The problems with residence rules have been noted before. According to The National Research Council (2004, p. 153),

The current definition of residence rules is confusing both to field enumerators and to residents. Difficulties arise for people with multiple residences, including those with movement patterns that are primarily within a week, or those that move seasonally. Such movement patterns are typically true of retirees, those involved in joint custody, arrangements, those with weekend homes in the country, students away at college during the school year, and people temporarily overseas. 
One common situation related to confusion about the occupants of a housing unit is people living in complex households (Schwede 2018). For example, West and Robinson (1999, p. 9) describe one situation that may lead to a child being missed in the Census.

A child who resides in a diverse household structure and in a unique living arrangement among multiple nuclear families...Unusual living arrangements involving people that make it difficult for the respondent to roster the household correctly on the Census form, e.g. presence of multiple nuclear families, unrelated people or step people of the respondent.

Complex households often involve the presence of subfamilies in a household and that can make correct rostering of household members more complicated. One official at the Census Bureau "...noted that she was aware of instances with multiple families, for example, where the household respondent did not include people in the second family" (cited in U.S. Census Bureau 2014, p. 16). Martin (2007) contends people more remotely linked to the person filling out the census questionnaire, are more likely to be missed.

A report from the U.S. Census Bureau (2016) indicates that many young mothers were not included in the 2010 American Community Survey (ACS) and therefore they argue many were probably unreported in the Census. Many of the young mothers missed in the ACS were probably single mothers with their child(ren) living with the parent(s) of the mother or with some other householder. It is feasible that the respondent believes the young mother and her children are only living with them temporarily and so does not enter them on the Census questionnaire roster. It is also easy to imagine a grandmother filling out the Census questionnaire may think of the young grandchild in her household as part of her daughters' family rather than part of her family.

A rapidly growing type of living arrangement for people (percentage-wise) is cohabitating households. Since cohabiting couples reflect living arrangements that are relatively unstable (compared to married-couple families) and the relationships among adults and children are different from those in a nuclear family, it would not be surprising if a disproportionately high share of people in cohabiting households were not being reported in the Census.

Newborns may be particularly likely to be living in complex households A recent report from the Census Bureau (Monte and Ellis 2014, p. 2) found "more than one in five women with a birth in the past 12 months reported at the time of the survey that they were living in someone else's home". In another analysis (Gooding 2008) shows that $13 \%$ of mothers were not co-residing with their biological child under age 1 and rates are higher for Blacks and Hispanics where the net undercount of people is also higher. This may help explain the high omissions rate for young children (O'Hare 2015). 


\subsection{Large and Complex Households}

People living in large households may be missed for many different reasons. First, large households are often complex households and people may be left off the questionnaire for reasons described in the previous section. Martin $(1999,2007)$ shows that being closely related to the respondent in a survey greatly decreases ambiguity related to residential attachment and complex households are more likely to have occupants who are not closely linked to the householder.

Examination of survey data taken prior to the 2010 Census shows that having more than two people in the household lowers the likelihood of respondents saying they will participate in the 2010 Census independent of other factors (Walejko et al. 2011). Data from the 2010 Census show that $84 \%$ of 2-person households mailed back their Census questionnaire compared to only $72 \%$ of 7-person households (Letourneau 2012).

Larger households are likely to contain children and child care demands may interfere with completing the Census questionnaire. This is a point made by Hillygus and colleagues (2006, p. 103) who note,

Respondents who are married with children have a lower mail-back rate ( 83 percent) than those who are married without children (90 percent), suggesting that the time demands of child care work against taking on this particular duty.

In a poll conducted just prior to the 2010 Census (Pew Research Center 2010) about a third of those who said there were not planning to participate in the 2010 Census cited "too busy or not enough time" as the reason.

\subsection{Confusion About What Types of People Should Be Included in the Census}

Another reason people are missed in the Census is because respondents may believe the Census Bureau does not want some categories of people included in the Census. In a series of short surveys by the Census Bureau (Nichols et al. 2014a, b, c) respondents were asked, "What information do you think the Census typically collects every 10 years?" and were offered several choices. The percentage who thought the Census Bureau collects "Names of children living at your address" was 7-9 percentage points lower than the percentage who thought the Census Bureau collects, "Names of adults living at your address". While this question asks about names rather than about information on individuals, it suggests that some people think the Census does not request information on children.

A recent report (Vargas 2018) based on a nationwide survey of Latinos conducted by the National Association of Latino Elected Officials found that $15 \%$ of respondents who had a child under age 5 in the home would not count them in the Census or do not know if they would count them. These attitudes help explain why young children 
have a higher omissions rate than any other age group in the 2010 Census (O'Hare 2015). Also, in their qualitative study of 2010 Census respondents Schwede and Terry (2013) indicated many respondents do not believe the Census Bureau (or the federal government) wants children included in the Census count.

Young children are not the only group some people think are not supposed to be included in the Census. Data from the Census Barriers Attitudes and Motivators Survey done in 2008, indicates only $76 \%$ of the people interviewed think the Census Bureau wants non-citizens included in the Census (U.S. Census Bureau 2009, p. 88). In a similar study in 2018 (U.S. Census Bureau 2018b) only 55\% of respondents were sure that noncitizens were supposed to be counted in the Census.

\subsection{People Deliberately Concealed}

There is evidence to support the idea that some people may be left off Census questionnaires on purpose. In some situations, there may be an effort to conceal an entire household, and in other situations the effort may be focused on concealing selected individual(s) within a household.

Some people may also be purposively left off census questionnaires based on rules about the housing unit where they are living. People could be left off because there are too many people living in the housing unit relative to rules about maximum capacity. If a housing unit is only supposed to have four people, by rule, but there are five people who regularly live there, one may be left of the census questionnaire because the respondent fears reporting five people in the unit might jeopardize continued occupancy.

Some people may be left off a census questionnaire because of the types of people who are allowed to live in a housing unit. For example, the report of the Census Bureau Task Force on the Undercount of People (U.S. Census Bureau 2014, p. 16) states one of the reasons people are left off forms is, "Respondents deliberately not mentioning kids for fear of some reprisals or bad outcomes from landlords, immigration agencies, social service agencies, etc". West and Robinson (1999, p. 7) also conclude,

Listing some members of the households may have other negative consequences. For example, a respondent may fear that disclosure of certain members of the household will affect eligibility for social services, that people illegally in the country will be deported, or that the whereabouts of a child in hiding from a custodial parent will be detected.

Pitkin and Park (2005) also mention "systematic concealment" as a potential reason children are undercounted in the Census.

Concealment may be driven by lack of trust in the Census Bureau and/or the federal government. Despite assurances from the about the confidentiality of responses to the Census (Congressional Research Service 2018), many people believe that data given to the Census Bureau may be shared with other government agencies. A poll (Pew Research Center 2010, p. 5) conducted just prior to the 2010 Census indicated that among those who said they were not planning to participate in the 2010 Census, 
$18 \%$ cited distrust of government and $8 \%$ cited privacy concerns. In the 2010 Census Barriers Attitudes and Motivators study (U.S. Census Bureau 2011) researchers classified $10 \%$ of the population as cynical and $14 \%$ as suspicious of the Census Bureau.

Census Bureau staff report growing number of respondents are refusing to cooperate because of fear (Meyers and Goerman 2018; U.S. Census Bureau 2017a, b). There is growing distrust of the federal government and for most people the Census Bureau is seen as another branch of the federal government. Abowd (2018) indicates that fear among undocumented population is also likely to be have an impact on many of the people who are in the country legally because they live in a household where undocumented people are living. One recent report concludes (Alsan and Yang 2018, p. i). "Though not at personal risk of deportation, Hispanic citizens may fear their participation could expose non-citizens in their network to immigration authorities". This report was focused on participation in safety net programs, but I think it applies to the Census as well.

Such distrust affects certain populations more than others. Immigrants are one population where concealment may be common because of fear of the federal government. The 2016 ACS (Table S0501) shows there are 43.7 million foreign-born residents in the U.S. and 22 million noncitizens. The Pew Research Center (2018) reports that there were about 11 million unauthorized immigrants in the U.S. in 2015. The estimate from the Pew Research Center is similar to estimate for January 2014 from Homeland Security (2018) of between 10.8 million and 12.1 million. This impacts not only noncitizens and undocumented immigrants but the people living in a household with them. There are 6.4 million children living in a household with at least on undocumented immigrant. Abowd (2018, p. 6) states, "From the 2016 ACS we estimate that $9.8 \%$ of all households contain at least one noncitizen". Almost all children less than 5 years old are citizens but $20 \%$ of children in this age range live with at least one noncitizen (Population Reference Bureau 2018).

\subsection{Barriers Posed by Questionnaire Design}

There are couple of aspects of the design of the Census questionnaire that may contribute to omissions in the Census. Both are related to rostering or listing all the people in the housing unit.

The first step in the Census-taking process is getting a respondent to list all the people in the household. This is called rostering. There is a lot of evidence indicating that the way rostering is done can impact who is included in the roster. For example, West and Robinson (1999, p. 6) conclude, "Coverage errors are likely to occur because the respondent has difficulty rostering his or her household". A recent paper by Battle and Bielick (2014) suggests that the inclusion of children may be particularly sensitive to the way rostering is done. An experiment by Tourangeau and colleagues (1997) found substantial variation in persons who were deemed to live at a given address with differing rostering instructions. Other researchers (Lin 
et al. 2004; Waller and Jones 2014) found rostering instructions very important in determining who is included in a given household. As stated earlier, the rules for whether someone should be listed as part of the household are not always clear to respondents. One perspective on the mismatch between the Census questionnaire and changing American families is provided by Jacobsen (2017) who contends, the Census Bureau's data collection methods have not kept pace with the rapidly changing American family.

It should be recognized that alternative ways of rostering households often have tradeoffs. Some rostering methods result in higher respondent burdens and rostering methods that impose a higher burden on respondents are likely to reduce response rates.

On the Mailout/Mailback Census questionnaire that was used in the 2010 Census there was only room for complete demographic information for six people in the household. There is limited room for the names and a few characteristics for the 7 th through the 12th person. If more than 12 people lived in the household, the Census Bureau had to follow up to get information for these people. For people living in the largest households (13 or more people) they may be missed because there is not enough room on the questionnaire for everyone in the household to be listed and follow up failed.

When incorrect or incomplete information is provided on the 2010 census questionnaire, the Census Bureau followed up with the household to get complete information for persons. But followup was often problematic, and the Census Bureau was only able to contact a little more than half the people in the 2010 Census followup operation (U.S. Census Bureau 2012d). The fact that followup was only done by telephone (not face to face follow up) also hampered data collection. Flaws in the followup operation may result in an omission. Heavy use of the internet for data collection in the 2020 Census may help lessen this issue because followup will be immediate on the internet.

\subsection{People Missed Because of Estimation and Processing Errors}

In addition to whole households being missed and people being left off census questionnaires, some people may not be reflected in the Census count because of processing errors in the Census operations. In particular, the final census counts include many people who are imputed and a large number who are included by proxy responses.

Imputations take several forms. The simplest form is item imputation. If a respondent leaves a census question (an item) blank, say race, the Census Bureau uses data from the person, the household, and the neighborhood to impute a race for the person. This might impact omissions figures for certain groups. For example, if a person who is really Black had their race imputed as White, the omissions for Blacks would look higher and the omissions for Whites would look lower. 
A bigger issue in terms of omissions is whole-person imputation. In the 2010 Census there were about 6 million persons imputed (U.S. Census Bureau 2012c, Table 9). This also takes several forms. If the Census Bureau enumerator has failed to find someone at home after repeated attempts, they may ask a proxy respondent such as a landlord of neighbor about the people living in the housing unit. It is not difficult to imagine a neighbor or landlord saying there are three people living in the housing unit when in fact they are four which results in an omission. Proxy responses provide low-quality data compared to self-reporting. The U.S. Census Bureau (2012b, Table 12) reports that $93 \%$ of responses from household members were correct compared to only $70 \%$ of those from proxies. The imputation methods of the Census Bureau have been refined over many censuses, but still may result in errors.

If after repeated visits when the Census Bureau enumerator found no one was at home, and no proxy respondent can be found, and the occupancy status of a housing unit is unclear, the Census Bureau imputes an occupancy status (occupied or vacant). If the imputed occupancy status is "occupied" the Census Bureau, then imputes the number and characteristics of people for the housing unit. It is easy to imagine a housing unit that really has four people living there, only gets three people imputed, and thus one person is omitted. It is also possible that several squatters may be living in a building that is imputed as vacant, so they are all missed in the census.

\subsection{Summary}

Several potential explanations for census omissions were examined and statistical data were provided for most potential explanations. While there is more support for some potential explanations that for others, no single reason or theory seems completely compelling. Perhaps the most fundamental conclusion from the material reviewed in this Chapter is that there are many different reasons why people are missed in the Census.

Some people are missed because the housing unit where they live is not included in the Census and others are missed because they are not captured in the Census even though others in the housing unit where they live are. Other findings include:

- People may be missed because they are more likely to live in complex or nontraditional households where their status in the household is unclear.

- Some people are missed because respondents are confused about who should be included on their Census questionnaire.

- People may be missed because respondents want to conceal them from the government, in part, because of fear or reprisals or negative outcomes.

- Some aspects of the census-taking process (like the construction of the questionnaire) result in some people being missed. 


\section{References}

Abowd, J. M. (2018). "Technical review of the department of justice request to add citizenship status question to the 2020 census," Memorandum for Wilbur L. Ross Jr., January 19, 2018.

Alsan, M., \& Yang, C. (2018). Fear and the safety net: evidence from secure communities. Working Paper 24731, National Bureau of Economic Research, Cambridge, MA.

Battle, D., \& Bielick, S. (2014). Differences in coverage and nonresponse when using a full household enumeration screener versus a child-only screener in a 2013 national mail survey, paper presented at annual conference of the American Association of Public Opinion Research. CA June: Anaheim.

Beimer, P. P., Groves, R. M., Lyberg, L. E., Mathiowetz, N. A., \& Sudman, S. (1991) Measurement errors in surveys. Wiley.

Congressional Research Service. (2018). "Confidentiality provisions for the 2020 decennial census," memorandum to house committee on oversight and government reform, From Jennifer Williams, dated April 19 Washington, DC.

de la Puente, M. (1993). Using ethnography to explain why people are missed or erroneously included by the census: evidence from small area ethnographic studies. Washington, DC: U.S. Census Bureau.

Fein, D. J. (1989). The social sources of census omissions: Racial and ethnic differences in omissions rates in recent U.S. censuses. Dissertation in Department of Sociology, Princeton University, Princeton, NJ.

Gooding, G. E. (2008). Differences between coresident and non-coresident women with a recent birth. Annual Meeting of the American Sociological Society, Boston, MA, August.

Groves, R. M., \& Couper, M. P., (1998). Nonresponse in household interview surveys. Wiley.

Hillygus, S. D., Nie, N. H., Prewitt, K., \& Pals, H. (2006). The hard count: The political and social challenges of census mobilization. New York, NY: Russell Sage Foundation.

Homeland Security. (2018). Estimates of the unauthorized immigration population residing in the United States, January 2014, Office of Immigration Statistics, Office of Strategy, Policy and Plans. https://www.dhs.gov/sites/default/files/publications/Unauthorized\%20Immigrant\% 20Population\%20Estimates\%20in\%20the\%20US\%20January\%202014_1.pdf.

Jacobsen, L. (2017). Discussion. Journal of Official Statistics, 33(4), 891-899.

Kassim, E., (2017). Differential undercount of mexican immigrant families in the U.S. Census. Statistical Journal of the IAOS, 33, 7979-816.

Letourneau, E. (2012). Mail response/return rates assessment, 2010 Census Planning Memorandum Series, No. 198, U.S. Census Bureau, Washington DC.

Lin, I. F., Schaeffer, N. C., \& Seltzer, J. A. (2004). Divorced parents qualitative and quantitative reports of children's living arrangements. Journal of Marriage and Family, 66, 385-397.

Mahler, S. (1993). Alternative enumeration of undocumented Salvadoreans on Long Island, Prepared under Joint Statistical Agreement 89-46 with Columbia University, Bureau of the Census, Washington DC.

Martin, E. (1999). Who knows who lives here? Within-household disagreements as a source of survey coverage error. Public Opinion Quarterly, 63, 220-236.

Martin, E. (2007). Strength of attachment: Survey coverage of people with tenuous ties to residences. Demography, 44(2), 437-440.

Martin, E., \& de la Puente, M., (1993). Research on sources of under coverage within households, U.S. Census Bureau, Washington, DC.

Meyers, M., \& Goerman, P. (2018). Respondents confidentiality concerns in multilingual pretesting studies and possible effects on response rates and data quality for the 2020 census. Paper delivered at the annual Conference of the American Association of Public Opinion Research, Denver CO., May 16-19, 2018.

Monte, L. M., \& Ellis, R. R. (2014). Fertility of women in the United States: 2012, Population Characteristics, P20-575, U.S. Census Bureau, Washington DC. 
National Research Council. (2013). Nonresponse in social science surveys. In R. Tourangeau \& T.J. Plewes (Eds.). Washington, DC: National Academy Press.

National Research Council. (2004). Reengineering the 2010 census: Risks and challenges. In D.L. Cork, M.L. Cohen, \& B.F. King (Eds.), Washington, DC: National Academy Press.

Nichols, E., King, R., \& Childs, J., (2014a). Small-scale testing pilot test results: Testing email and address collection screens and Census opinion questions using a nonprobability panel. Internal memorandum to Burton Reist. Census Bureau (March 27).

Nichols, E., King, R., \& Childs, J., (2014b). 2014 march small-scale testing pilot test results: Testing email subject lines, email formats, address collection screens and Census opinion questions using a nonprobability panel. Internal memorandum to Burton Reist. Census Bureau (May 27).

Nichols, E., King, R., and Childs, J., (2014c). May 2104 small-scale testing results: Testing email subject lines, email formats, address collection screens and Census opinion questions using a nonprobability panel. Internal memorandum to Burton Reist. U.S. Census Bureau. (September 9).

O'Hare, W. P., (2015) The undercount of young children in the U.S. decennial census. Springer Publishers.

Olson, D. B. (2009). A three-phase model of census capture. Paper presented at the Joint Statistical Meetings.

Pew Research Center. (2010). Age, education, ethnic and partisan gaps: Most view census positively, but some have doubts. New Release January 20, Washington DC.

Pew Research Center. (2018). 5 facts about illegal immigration in the U.S., fact tank downloaded, July 15, 2018. http://www.pewresearch.org/fact-tank/2017/04/27/5-facts-about-illegalimmigration-in-the-u-s/.

Pitkin, J., \& Park, J. (2005). The gap between births and census counts of people born in California: undercount or transnational movement? Paper presented at the Population Association of America Conference, Philadelphia PA, March.

Population Reference Bureau (2018). Citizenship question risks a 2020 census undercount in every state, especially among children. Population Reference Bureau, Washington DC.

Robinson, J. C., \& Bruce, A. (2007). The planning database: decennial census data for historical, real-time, and prospective analysis, paper presented at Joint Statistical Meetings, 2007, Salt Lake City.

Schwede, L. (2018). Linkages among the rise in complex households, the undercount of young children, and race/ethnicity: where we have been and where we might go for the 2020 census. Poster Presented at the 2018 Annual Conference of the Population Association of America, Denver, CO, April

Schwede, L., \& Terry, R., (2013). Comparative ethnographic studies of enumeration methods and coverage across race and ethnic groups, 2010 Census Program for Evaluations and Experiments, U.S. Census Bureau, Washington, DC.

Schwede, L., Terry, R., \& Hunter, J. (2015). Ethnographic evaluations on coverage of Hard-toCount minority in the US decennial censuses. In R. Tourangeau, B. Edwards, T. P. Johnson, K. M. Wolter, \& N. Bates (Eds.), Hard-to-survey populations (pp. 293-315). Cambridge, England: Cambridge University Press.

Simpson, L., \& Middleton, E., (1997). Who is missed by a national census? A review of empirical results from Australia, Britain, Canada, and the USA. The Cathie Marsh Centre for Census and Survey Research, University of Manchester UK.

Tourangeau, R., Shapiro, G., Kearney, A., \& Ernst, L. (1997). Who lives here? Survey undercoverage and household roster question. Journal of Official Statistics, 13(1), 1-18.

U.S. Census Bureau. (1992). “Barriers Paper,” Memorandum for Susan M. Miskura from LaVerne V. Collins, October 29. Washington, DC: U.S. Census Bureau.

U.S. Census Bureau. (2009). Census barriers, attitudes, dan motivators survey. C2PO 2010 Census Integrated Community Research Memorandum Series, No. 11, May 18. Washington, DC: U.S. Census Bureau. 
U.S. Census Bureau. (2011). Census barriers, attitudes, dan motivators survey II final report. 2010 Census Planning Memorandum Series, No. 205, June 26. Washington, DC: U.S. Census Bureau.

U.S. Census Bureau. (2012a). 2010 census coverage measurement estimation report: summary of estimates of coverage for housing units in the United States. DSSD 2010 census coverage measurement memorandum series \#2010-G-02, May 22, 2012. Washington, DC: U.S. Census Bureau.

U.S. Census Bureau. (2012b). 2010 census coverage measurement estimation report: Components of census coverage for the household population in the United States. 2010 Census coverage measurement memorandum series \#2010-G-04. Washington, DC: U.S. Census Bureau.

U.S. Census Bureau. (2012c). 2010 census coverage measurement estimation report: Summary of estimates of coverage for persons in the United States. DSSD 2010 CENSUS COVERAGE MEASUREMNET MEMORANDUM SERIEs \#2010-G-01. Washington, DC: U.S. Census Bureau.

U.S. Census Bureau. (2012d). 2010 census effectiveness of unduplication evaluation report. 2010 Census Planning Memorandum Series, No. 244,Washington, DC: U.S. Census Bureau, October.

U.S. Census Bureau. (2014). Final task force report: Task force on the undercount of young children. Memorandum for Frank A. Vitrano. Washington, DC: U.S. Census Bureau. February 2.

U.S. Census Bureau. (2016). 2020 census research and testing, investigating the 2010 undercount of young children-Examining the coverage of young mothers. Washington, DC, U.S: Census Bureau,

U.S. Census Bureau. (2017a). "Respondent confidentiality concerns,” Memorandum for Associate Directorate for Research and Methodology (ADRM) From Center for Survey Measurement (SCM), September 20, 2017.

U.S. Census Bureau. (2017b). Respondent confidentiality concerns and possible effects on response rates and data quality for the 2020 census. Presentation by Mikelyn Meyers at the Census Bureau National Advisory Committee Meeting, November 2, 2017.

U.S. Census Bureau. (2018a). Downloaded from American Factfinder Table DP-1.

U.S. Census Bureau. (2018b). 2020 Census barriers, attitudes, and motivators study (CBAMS) survey and focus groups: Key findings for NAC. Presentation to the U.S. Census Bureau's National Advisory Group, November 1, 2108, slide 16.

Vargas, A. (2018). Slides from a webinar entitled census 2020: Research and messaging September 12. Available at https://drive.google.com/file/d/1QUga5owRyQyQY6IegH10i8ZkCrLalRkH September 12/view.

Walejko, G. K., Miller, P. V., \& Bates, N. (2011). Modeling intended 2010 census participation. Paper delivered at the American Association of Public Opinion Research conference, Phoenix, AZ, May 30, 2011.

Waller, M. R., \& Jones, M. R. (2014). Who is the residential parent? Understanding discrepancies in unmarried parents' reports. Journal of Marriage and Family, 76, 73-93.

West, K. K., \& Fein, D. J. (1990). Census undercounts: An historical and contemporary sociological issue. Sociological Inquiry, 60(2), 127-141.

West, K., \& Robinson, J. G., (1999). What do we know about the undercount or children? U.S. Census Bureau, Population Division working paper. Washington. DC: U.S. Census Bureau. 
Open Access This chapter is licensed under the terms of the Creative Commons Attribution 4.0 International License (http://creativecommons.org/licenses/by/4.0/), which permits use, sharing, adaptation, distribution and reproduction in any medium or format, as long as you give appropriate credit to the original author(s) and the source, provide a link to the Creative Commons license and indicate if changes were made.

The images or other third party material in this chapter are included in the chapter's Creative Commons license, unless indicated otherwise in a credit line to the material. If material is not included in the chapter's Creative Commons license and your intended use is not permitted by statutory regulation or exceeds the permitted use, you will need to obtain permission directly from the copyright holder.

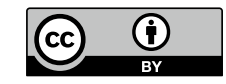

